\title{
Low evidence for extra-pair fertilizations in two reintroduced populations of Griffon Vulture (Gyps fulvus)
}

\author{
Pascaline Le Gouar $\cdot$ Justine Sulawa $\cdot$ \\ Sylvain Henriquet · Christian Tessier • \\ François Sarrazin
}

Received: 23 October 2009/Revised: 3 August 2010/Accepted: 28 September 2010/Published online: 21 October 2010

(C) The Author(s) 2010. This article is published with open access at Springerlink.com

\begin{abstract}
The Griffon Vulture (Gyps fulvus) is considered to be socially monogamous. However, extra-pair fertilizations are suspected due to observations of extra-pair copulations in some populations. We performed parentage studies based on ten polymorphic microsatellite markers in two reintroduced colonies of Griffon Vulture. Out of 40 genotyped chicks, we found eight chicks whose genotypes mismatched those of their observed parents. Two could be explained by the occurrence of a null allele at one locus. The six remaining mismatches detected relied on mismatches at one locus, and they were not detected when we increased the potential genotyping error rate. We thus conclude that the Griffon Vulture is genetically monogamous, at least in low-density populations.
\end{abstract}

Communicated by M. Wink.

P. Le Gouar $(\varangle) \cdot$ J. Sulawa · F. Sarrazin

UMR 7204, Conservation des espèces,

restauration et suivi des populations,

61 rue Buffon, 1er étage, 75005 Paris, France

e-mail: pascalinelegouar@free.fr

P. Le Gouar

NIOO-KNAW, Vogeltrekstation, Boterhoeksestraat 48, 6666 Heteren, GA, The Netherlands

J. Sulawa

Leibniz Institute for Zoo and Wildlife Research,

P.O. Box 601103, 10252 Berlin, Germany

S. Henriquet

LPO PACA antenne Verdon, 5 Boulevard Saint-Michel,

04120 Castellane, France

C. Tessier

Association Vautours en Baronnies,

Mairie 26510 Rémuzat, France
Keywords Extra-pair paternity · Vulture .

Reintroduction · Genetic

Zusammenfassung Es wird angenommen, dass Gänsegeier (Gyps fulvus) monogam leben. Da aber außerpartnerschaftliche Kopulationen beobachtet wurden, ist anzunehmen, dass es auch Fremdvaterschaften gibt. Wir untersuchten Verwandtschaft anhand von zehn polymorphen Mikrosatellitenmarkern in zwei wiedereingebürgerten Gänsegeierkolonien. Von 40 genotypisch untersuchten Küken passten acht nicht zu ihren sozialen Eltern. Zwei dieser Abweichungen ließen sich auf Nullallele an einem Lokus zurückführen. Die sechs Übrigen kamen durch eine Abweichung an einem Lokus zustande und wurden nicht mehr entdeckt, als wir den Fehlerspielraum des genetischen Typisierung erhöhten. Wir schließen daraus, dass Gänsegeier zumindest in wenig dichten Kolonien genetisch monogam sind.

\section{Introduction}

Monogamy was long considered to be the dominant mating system in birds, but advances in molecular techniques have revealed high levels of extra-pair fertilizations (EPFs) among many avian species (Avise 1996; Griffith et al. 2002). EPFs influence the variability of reproductive success among individuals and thus individual fitness and effective population size (Castro et al. 2004), which are important measures for the conservation of endangered species. The Griffon Vulture (Gyps fulvus) was highly endangered across its range in the middle of the twentieth century, and local extinctions occurred in France (Terrasse 1983). Conservation actions and successful reintroduction 
programs restored Griffon Vulture populations in southwestern Europe (Terrasse et al. 2004). The Griffon Vulture is a long-lived colonial scavenger that is considered to be sexually monomorphic and socially monogamous (Roselaar 1979; Mendelssohn and Leshem 1983). The species typically has long-term pair bonds, although some divorces had been observed (Sarrazin et al. 1996). Several facts led researchers to suspect that EPFs could occur in this species despite a lack of confirmation by genetic analysis. First, the Griffon Vulture is a colonial nester, and pursuit of extrapair copulations (EPCs) by females has been suggested as a determinant of coloniality evolution (Wagner 1993; Hoi and Hoi-Leitner 1997). Second, EPC has already been reported in Old World vultures (Negro and Grande 2001), and recently for the studied species (Xirouchakis and Mylonas 2007). In contrast, due to the low fecundity rate in Griffon Vultures, i.e., only one egg per year, intraspecific brood parasitism or "egg dumping" is unlikely to occur (Arnold and Owens 2002). We studied whether EPFs occurred in two reintroduced populations of Griffon Vulture using parentage analysis on DNA microsatellite fingerprinting.

\section{Methods}

\section{Studied populations}

The Griffon Vulture was reintroduced to three areas in the French Alps from 1996 to 2004. In Baronnies, 56 birds were released from 1996 to 2001. In Verdon and Vercors, respectively, 91 and about 60 vultures have been reintroduced since 1999. All released birds were marked with an engraved Darvic ring that allows long-distance identification. Their first chicks hatched in the wild in 1999 in Baronnies and in 2002 in Verdon. No successful reproduction was observed in Vercors before 2008. In 2004, 45 pairs bred in Baronnies and 11 in Verdon. During the studied period, 124 reproduction events have been observed in 59 nests in Baronnies, and 28 reproduction events in 25 nests in Verdon. All chicks were marked at their nests. During chick ringing, parents left the nest before the ringer reached the nest. During the breeding period (from December to August), breeding birds were identified on nests using a spotting scope $(\times 60)$. Distance to nest varied from 300 to $800 \mathrm{~m}$. Duration of observation of each nest varied from 1 to $5 \mathrm{~h}$, depending on the activity level of the breeders. Observations of one adult taking over nest duty from another adult allowed us to confirm their breeding status. Frequently, breeders' rings could not be read during the five hours of observation when breeders were inactive. Some birds could not be identified due to ring losses. Therefore, despite regular monitoring of pairs throughout the breeding season, identification relied on only a few records. Basic information on rings (at least presence/absence) were available for 192 out of the 248 breeders in Baronnies and 50 out of the 56 breeders in Verdon. One hundred forty-four breeders, of which 65 were successful breeders, were identified in Baronnies, whereas 42 breeders, of which 30 were successful ones, were identified in Verdon. These identifications were used to build "observed" genealogies of chicks that hatched from 2001 to 2004 in Baronnies and from 2002 to 2004 in Verdon.

\section{Molecular and parentage analysis}

Blood or feathers were taken from most of the released individuals. Growing feathers of hatched chicks were collected during ringing and stored in $70 \%$ ethanol. All sampled individuals were sexed with molecular techniques (Bosé et al. 2007). This molecular sexing allowed us to discard observations of two individuals of the same sex breeding with each other. For instance, two females were observed breeding in Baronnies. We excluded this pair from the analysis of EPFs. Using ten microsatellite markers (GF3F3, GF3H3, GF8G1, GF9C1, and GF11A4 from Mira et al. 2002; GVBV11, GVBV12, GVBV13, GVBV17, and GVBV20 from Gautschi et al. 2000), we genotyped all sampled individuals (for protocol, see Le Gouar et al. 2008). DNA extracted with the CTAB method (Le Gouar et al. 2008) from blood and growing feathers were highly concentrated. Some individuals were genotyped 3-4 times to determine how many amplifications were needed to obtain a reliable genotype. Both heterozygous and homozygous genotypes were reliable with one amplification since we found the same genotype for all the amplifications. However, in some rare cases, some loci did not amplify. We thus considered individuals with fewer than four missing loci (only 4 individuals were discarded). Among these, we selected potential parents in the Baronnies and Verdon colonies as those individuals that were believed to have resided in the colonies during breeding season (i.e., those that were neither dead nor seen in another colony). We checked for identical genotypes in the data set.

We computed allele frequencies, mean number of alleles by locus, as well as expected and observed heterozygosity rates using GENETIX 4.02 software (Belkhir et al. 1996). Several technical and biological hurdles independent from EPF, such as null alleles, linkage disequilibrium, mutations and scoring errors, could lead to microsatellite genotyping discrepancies (Hoffman and Amos 2005). Because null alleles, which result from the amplification failure of one allele, lead to scoring a heterozygote individual as homozygous, their occurrence could be suspected if an excess of homozygotes (i.e., Hardy-Weinberg disequilibrium) is 
detected. Departure from Hardy-Weinberg equilibrium (HWE) for each locus and genotypic disequilibrium were tested for using a Markov chain, as implemented in GENEPOP 3.4 software (Raymond and Rousset 1995). Additionally, we computed for each locus the average nonexclusion probability for the identities of two unrelated individuals (PID) and of two siblings (PIDsib), and the estimated null allele frequency using the program Cervus 3.0 (Kalinowski et al. 2007).

For parentage analysis, we used the categorical allocation method implemented in the FAMOZ software (Gerber et al. 2003) to construct the "genetic" genealogy. This method assigned offspring to parents and to pairs based on likelihood score calculations (LOD score) derived from genotypes and allele frequencies (Jones and Ardren 2003). To define statistical LOD score thresholds for parents and pairs, we computed simulations of 10,000 offspring for each population. As mutations and scoring errors always occurred in the data sets, we first introduced a proportion of 0.001 typing error into both the LOD score calculation and the simulations. We then increased this rate to 0.1 to span the error rate variation reported in Hoffman and Amos 2005. Parents and pairs with LOD scores above the threshold were considered to be true genetic parents (Gerber et al. 2003). We then compared the "genetic" genealogy and the "observed" genealogy to test whether EPF occurred. When mismatches between observed and genetic genealogy were revealed, genotypes were confirmed by additional independent tests.

\section{Results}

The proportion of identified breeders decreased in Baronnies from $100 \%$ in 1999 to $21 \%$ in 2004, and was exhaustive each year in Verdon. Some individuals released in Vercors and in Verdon were observed breeding in Baronnies. Among identified parents, 35 (54\%) were genotyped in Baronnies (20 males, 14 females and one unsexed parent) and 15 (50\% of identified parents) in Verdon (9 males and 8 females). We genotyped 30 chicks that hatched from 2001 to 2004 in Baronnies, and we selected 48 potential genotyped parents. In Verdon, the number of genotyped chicks hatched from 2002 to 2004 was 10 , and 24 potential genotyped parents were considered. All microsatellite markers were polymorphic, and the mean number of alleles by locus was 6.1 for Baronnies and 5.4 for Verdon. No identical genotypes were found in the data set. The cumulative probability of identity for unrelated individuals was $<0.0001$, and that for siblings was 0.0009 . We found no linkage disequilibrium between loci. Observed and expected heterozygosity rates were, respectively, $0.589( \pm 0.244)$ and $0.573( \pm 0.238)$ in Baronnies and $0.532( \pm 0.285)$ and
$0.540( \pm 0.255)$ in Verdon. Global tests for deficits of heterozygotes from HWE were not significant in both populations. However, departure from HWE was detected at locus GF11A4 in both populations. The null allele frequency at this locus was estimated to be 0.07 .

For both populations, mismatches between observed and genetic genealogy were detected with error rates of 0.001 . These mismatches (confirmed with two repeated amplifications) involved one father and two mothers in Baronnies and one father in Verdon (Table 1). In Baronnies, one extra-pair paternity event was suspected because of a mismatch between the heterozygous genotypes of a father and two putative chicks born in 2002 and 2005 at locus GVBV12 (Table 1). One female with a homozygous genotype at GF3H3 (146/146) was excluded as a potential parent of a chick with a heterozygous genotype at this locus (136/144). In Verdon, one father was excluded because of a mismatch between its heterozygous genotype and the genotypes of three putative chicks born in 2002, 2003 and 2004, respectively, at locus GF9C1 (Table 1). Those discrepancies were not significant when adopting an error rate of 0.1 . By contrast, with error rates of 0.001 and 0.1 , one female in Baronnies was excluded as a possible mother of two offspring because of a mismatch between their genotypes at locus GF11A4. Both offspring were homozygous at this locus with different alleles from the heterozygous genotype of the putative mother.

\section{Discussion}

Our results showed little evidence of EPF in Griffon Vultures. Concerning evidence of extra-pair paternity, two males were observed breeding with the same female during several consecutive years, which supports accurate identification of these males. Consistent genotypes of offspring indicated that they have the same father, which suggests that the extra-pair male was the same each year. However, when we increased the rate of potential genotyping errors, none of the extra-pair paternities and only half of the occurrences of intraspecific brood parasitism were detected. Although independent retests were performed, microsatellite genotyping error could still occur because of allele dropout, mutation or a null allele. Checking for allele dropout using the whole Griffon Vulture genotype dataset $(n=796)$, we found low percentages $(<5 \%)$ of allele dropout for all loci. Mutations in microsatellite markers often involved single- or two-step mutations (one or two repeat units), and occurred more often for markers of larger sizes (Ellegren 2000). Mismatches due to one or two repeat differences at the GF9C1 and GVBV12 loci, two largesized markers, led to the detection of EPF, questioning the occurrence of mutations at those loci. A null allele was 
Table 1 Genetic discrepancies in genealogies revealed with 0.001 genotyping error in Baronnies and Verdon colonies

\begin{tabular}{|c|c|c|c|c|c|c|c|c|c|c|}
\hline & GF11A4 & GVBV17 & GF9C1 & GF3H3 & GF3F3 & GVBV20 & GVBV13 & GVBV12 & GVBV11 & GF8G1 \\
\hline Percentage of missing data & 0 & 28 & 2.3 & 4.6 & 0.6 & 1.7 & 1.1 & 1.7 & 1.1 & 21 \\
\hline Null allele frequency & 0.075 & 0.033 & 0.011 & 0.003 & 0.043 & 0.0004 & 0.028 & 0.012 & 0.027 & 0.016 \\
\hline PID & 0.05 & 0.41 & 0.04 & 0.09 & 0.49 & 0.22 & 0.60 & 0.03 & 0.18 & 0.45 \\
\hline PIDsib & 0.35 & 0.63 & 0.33 & 0.39 & 0.71 & 0.51 & 0.78 & 0.32 & 0.49 & 0.67 \\
\hline \multicolumn{11}{|l|}{ Baronnies } \\
\hline \multicolumn{11}{|l|}{ Nest A } \\
\hline Observed father & $130-140$ & - & $254-254$ & $144-146$ & $176-178$ & $137-137$ & $176-176$ & $242-268$ & $164-170$ & - \\
\hline Observed mother & $130-135$ & $184-184$ & $264-268$ & $136-146$ & $176-176$ & 139-139 & $176-176$ & $238-254$ & $162-162$ & $278-278$ \\
\hline Chick2002 & $135-140$ & 184-186 & $254-268$ & $136-146$ & $176-176$ & $137-139$ & $176-176$ & $238-266$ & $162-164$ & $278-278$ \\
\hline Chick2005 & $130-130$ & 184-184 & $254-268$ & $136-144$ & $176-178$ & 137-139 & $176-176$ & $238-266$ & $162-164$ & - \\
\hline \multicolumn{11}{|l|}{ Nest B } \\
\hline Observed father & $130-135$ & $184-184$ & $254-266$ & $136-144$ & $176-176$ & $137-137$ & $176-178$ & $220-240$ & $162-164$ & $278-278$ \\
\hline Observed mother & $135-150$ & - & $256-260$ & $146-146$ & $176-176$ & $137-139$ & $176-178$ & $236-240$ & $158-162$ & $276-278$ \\
\hline Chick2001 & $130-135$ & $184-186$ & $254-260$ & 136-144 & $176-176$ & 137-139 & $178-178$ & $236-240$ & $162-164$ & $276-278$ \\
\hline \multicolumn{11}{|l|}{ Nest C } \\
\hline Observed mother & 125-155 & $184-184$ & $262-262$ & $142-146$ & $176-178$ & $139-139$ & $176-176$ & $238-238$ & $162-162$ & $278-278$ \\
\hline Chick2003 & $130-130$ & $184-184$ & $260-262$ & $144-146$ & $176-178$ & $137-139$ & $176-176$ & $236-238$ & $162-162$ & $278-278$ \\
\hline Chick2004 & $135-135$ & $184-184$ & - & $144-146$ & $176-176$ & $137-139$ & $176-176$ & - & - & - \\
\hline \multicolumn{11}{|l|}{ Verdon } \\
\hline \multicolumn{11}{|l|}{ Nest $\mathrm{D}$} \\
\hline Observed father & $135-140$ & - & $260-266$ & $136-146$ & $176-176$ & $137-137$ & $176-176$ & $236-240$ & $158-164$ & $278-278$ \\
\hline Observed mother & $140-140$ & $184-184$ & $254-254$ & $138-142$ & $176-176$ & $139-141$ & $176-176$ & $240-240$ & $158-162$ & $278-278$ \\
\hline Chick2002 & $135-140$ & $184-186$ & $254-256$ & $138-146$ & $176-176$ & $137-139$ & $176-176$ & $240-240$ & $158-164$ & - \\
\hline Chick2003 & $140-140$ & 184-186 & $254-256$ & $136-142$ & $176-176$ & - & $176-176$ & $236-240$ & $158-162$ & - \\
\hline Chick2004 & $140-140$ & 184-184 & $254-256$ & $142-146$ & $176-176$ & $137-139$ & $176-176$ & $240-240$ & $162-164$ & $278-278$ \\
\hline
\end{tabular}

For each locus, percent of missing data, null allele frequency, average probability that the genotypes at a single locus do not differ between two unrelated individuals (PID), and average probability that the genotypes at a single locus do not differ between two full siblings (PIDsib) are presented. Mismatches are given in bold. The year of birth of each chick is indicated. A dash alone in a cell indicates no amplification

suspected for one locus (GF11A4) because of a high proportion of observed homozygotes compared to expectations under HWE. Consequently, the EPF revealed by a mismatch at this locus should be considered with caution, especially if it involves a homozygous genotype, as was the case for one female in Baronnies. Therefore, intraspecific brood parasitism evidence could be discarded due to the potential for a null allele at the locus of mismatch. Concerning EPFs, only sequencing of the relevant regions would allow us to discard technical problems as the source of mismatches rather than biological ones.

The low occurrence of EPF could be due to the low breeding densities of the studied populations. Several studies have found that breeder density and extra-pair paternity rate are positively correlated among populations of the same species (Møller and Ninni 1998), but they failed to determine if this relationship was causal or due to other covariate factors (Griffith et al. 2002). Nonetheless, our results agree with those of other studies on socially monogamous species of raptors that revealed low to null rates of EPFs (Rudnick et al. 2005; Saladin et al. 2007). Our results suggest that Griffon Vultures are genetically monogamous. Indeed, strict monogamy in vultures has been debated because EPCs have been observed. Their frequencies are usually low in wild-born populations $(3.3 \%$ in Griffon Vulture, Xirouchakis and Mylonas 2007; 0.5\% in Cape Griffon, Gyps coprotheres, Mundy et al. 1992; $0.52 \%$ in Bearded Vulture, Gypaetus barbatus, Bertran and Margalida 1999; $2.6 \%$ in Egyptian Vulture, Nephron percnopterus, Donázar et al. 1994), but Mee et al. (2004) observed an EPC frequency of $23 \%$ in a reintroduced population of California Condor, Gymnogyps californianus. They argued that EPCs may be enhanced in reintroduced populations because of increasing social interactions due to the concentration of food at a few feeding stations, limited mate choice, and a high degree of inbreeding among breeders (Mee et al. 2004). If we assume that EPCs led to EPFs, our results contrast with the observations of Mee et al. However, there could be a high frequency of EPCs but a low level of EPFs, as in the monogamous Lanyus scops 
owl (Hsu et al. 2006). The limitation on EPFs could be also due to a high copulation rate between partners of the same breeding pair. Indeed, high copulation rates are common in raptors (Mougeot et al. 2002), and are supposed to be an effective behavior for ensuring male paternity, fidelity and investment in chick rearing for the female (Hunter et al. 1993; Birkhead and Møller 1998). Moreover, the high investment of each parent in chick rearing restrains them from seeking EPC (Saladin et al. 2007).

The low to null EPF rate observed here, which must be confirmed in larger populations, makes it possible to directly estimate the effective population size from a breeding pair census.

Acknowledgments This study is the result of a collaboration among various organizations: the LPO PACA and the Association "Vautours en Baronnies" (who were in charge of monitoring Griffon Vultures at the two studied sites), and the Service de Systématique Moléculaire (FR 1541) of the National Museum of Natural History in Paris (who performed the molecular analyses). We thank O. Lannés, who collected tissue samples. We are very grateful to M. Bosé and F. Rigal, who provided some DNA extracts. We also thank M.C. Boisselier, J. Lambourdière and C. Bonillo for advice and technical support. The French Ministries of Research and Ecology and Sustainable Development provided funding. The experiments comply with the current laws of France, in which they were performed.

Open Access This article is distributed under the terms of the Creative Commons Attribution Noncommercial License which permits any noncommercial use, distribution, and reproduction in any medium, provided the original author(s) and source are credited.

\section{References}

Arnold KE, Owens IPF (2002) Extra-pair paternity and egg dumping in birds: life history, parental care and the risk of retaliation. Proc R Soc Biol Sci Ser B 269:1263-1269

Avise JC (1996) Three fundamental contributions of molecular genetics to avian ecology and evolution. Ibis 138:16-25

Belkhir K, Borsa P, Chikhi L, Raufaste N, Bonhomme F (1996) GENETIX, logiciel sous Windows TM pour la génétique des populations. Laboratoire Génome, Populations, Interactions, CNRS UMR 5000. Université de Montpellier II, Montpellier

Bertran J, Margalida A (1999) Copulatory behaviour of the bearded vulture. Condor 101:164-168

Birkhead TR, Møller AP (1998) Sperm competition and sexual selection. Academic, London

Bosé M, Le Gouar P, Arthur C, Lambourdière J, Choisy JP, Henriquet S, Lécuyer P, Richard M, Tessier C, Sarrazin F (2007) Does sex matter in reintroduction of griffon vultures (Gyps fulvus)? Oryx 41:503-508

Castro I, Mason KM, Armstrong DP, Lambert DM (2004) Effect of extra-pair paternity on effective population size in a reintroduced population of the endangered hihi, and potential for behavioural management. Conserv Genet 5:381-393

Donázar JA, Ceballos O, Tella JL (1994) Copulation behaviour in the Egyptian vulture. Bird Study 41:37-41

Ellegren H (2000) Microsatellite mutations in the germline: implication for evolutionnary inference. Trends Genet 16:552-558
Gautschi B, Tenzer I, Müller JP, Schmid B (2000) Isolation and characterization of microsatellite loci in the bearded vulture (Gypaetus barbatus) and cross-amplification in three Old World vulture species. Mol Ecol 9:2155-2234

Gerber S, Chabrier P, Kremer A (2003) FAMOZ: a software for parentage analysis using dominant, codominant and uniparentally inherited markers. Mol Ecol Notes 3:479-481

Griffith SC, Owens IPF, Thuman KA (2002) Extra pair paternity in birds: a review of interspecific variation and adaptive function. Mol Ecol 11:2195-2212

Hoffman JI, Amos W (2005) Microsatellite genotyping errors: detection approaches, common sources and consequences for paternal exclusion. Mol Ecol 14:599-612

Hoi H, Hoi-Leitner M (1997) An alternative route to coloniality in the bearded tit: females pursue extra-pair fertilizations. Behav Ecol 8:113-119

Hsu Y-C, Li S-H, Lin Y-S, Philippart MT, Severinghaus LL (2006) High frequency of extra-pair copulation with low level of extrapair fertilization in the Lanyu scops owl Otus elegans botelensis. J Avian Biol 37:36-40

Hunter FM, Petrie M, Otronen M, Birkhead TR, Møller AP (1993) Why do females copulate repeatedly with one male? Trends Ecol Evol 8:21-26

Jones AG, Ardren WR (2003) Methods of parentage analysis in natural populations. Mol Ecol 12:2511-2523

Kalinowski ST, Taper ML, Marshall TC (2007) Revising how the computer program CERVUS accommodates genotyping error increases success in paternity assignment. Mol Ecol 16:1006-1099

Le Gouar P, Rigal F, Boisselier-Dubayle M, Sarrazin F, Arthur C, Choisy J, Hatzofe O, Henriquet S, Lécuyer P, Tessier C, Susic G, Samadi S (2008) Genetic variation in a network of natural and reintroduced populations of Griffon vulture (Gyps fulvus) in Europe. Conserv Genet 9:349-359

Mee A, Ausin G, Barth M, Beestman C, Smith T, Wallace M (2004) Courtship behaviour in reintroduced California condors: evidence for extra-pair copulations and female mate guarding. In: Chancelor RD, Meyburg BU (eds) Raptors worldwide: proceedings of the VI World Conference on Birds of Prey and Owls. WGBP/MME, Hungary, pp 75-81

Mendelssohn H, Leshem Y (1983) Observations on reproduction and growth of Old World vultures. In: Wilbur SR, Jackson JA (eds) Vulture biology and management. University of California Press, Los Angeles, pp 214-241

Mira S, Billot C, Guillemaud T, Palma L, Cancela ML (2002) Isolation and characterization of polymorphic microsatelitte markers in Eurasian vulture Gyps fulvus. Mol Ecol Notes 2:557-558

Møller AP, Ninni P (1998) Sperm competition and sexual selection: a meta-analysis of paternity studies of birds. Behav Ecol Sociobiol 43:345-358

Mougeot F, Thibault JC, Bretagnolle V (2002) Effects of territorial intrusions, courtship feedings and mate fidelity on the copulation behaviour of the osprey. Anim Behav 64:759-769

Mundy P, Butchart D, Ledger J, Piper S (1992) The vultures of Africa. Academic, London

Negro JJ, Grande JM (2001) Territorial signalling: a new hypothesis to explain frequent copulation in raptorial birds. Anim Behav 62:803-809

Raymond M, Rousset F (1995) GENEPOP (version 1.2): population genetic software for exact tests and ecumenicism. J Hered $86: 248-249$

Roselaar CS (1979) The birds of the Western Palearctic. Oxford University Press, Oxford

Rudnick JA, Katzner TE, Bragin EA, Rhodes E, Dewoody JA (2005) Using naturally shed feathers for individual identification, genetic parentage analyses, and population monitoring in an 
endangered Eastern imperial eagle (Aquila heliaca) population from Kazakhstan. Mol Ecol 14:2959-2967

Saladin V, Ritschard M, Roulin A, Bize P, Richner H (2007) Analysis of genetic parentage in the Tawny owl (Strix aluco) reveals extra-pair paternity is low. J Ornith 148:113-116

Sarrazin F, Bagnolini C, Pinna J-L, Danchin E (1996) Breeding biology during establishment of a reintroduced griffon vulture Gyps fulvus population. Ibis 138:315-325

Terrasse M (1983) The status of vultures in France. In: Wilbur SR, Jackson JA (eds) Vulture biology and management. University of California Press, Los Angeles, pp 81-85

Terrasse M, Sarrazin F, Choisy J-P, Clémente C, Henriquet S, Lécuyer P, Pinna J-L, Tessier C (2004) A success story: the reintroduction of Eurasian Griffon Gyps fulvus and Black Aegypius monachus vultures to France. In: Chancelor RD, Meyburg BU (eds) Raptors worldwide: proceedings of the VI World Conference on Birds of Prey and Owls. WGBP/MME, Hungary, pp 127-145

Wagner RH (1993) The pursuit of extrapair copulations by female birds: a new hypothesis of colony formation. $\mathrm{J}$ Theor Biol 163:333-346

Xirouchakis SM, Mylonas M (2007) Breeding behaviour and parental care in the Griffon Vulture Gyps fulvus on the island of Crete (Greece). Ethol Ecol Evol 12:1-26 